\title{
Anthropogenic pollutants - an insidious threat to animal health and productivity?
}

\author{
Stewart M Rhind \\ From Environmental contaminants and animal health. The 26th Symposium of the Nordic Committee for \\ Veterinary Scientific Cooperation (NKVet) \\ Helsinki, Finland. 6-7 October 2011
}

\begin{abstract}
Summary
Humans have always polluted their environment and, to an extent, the associated adverse consequences have increased in parallel with the global population. However, in recent decades, entirely novel compounds have been created, for multiple purposes, and some of these have become ubiquitous, damaging pollutants, which interfere with fundamental physiological processes in all animal species, disrupting reproductive and other functions. Understanding of the actions of these chemicals is poor but it is recognised that they can act additively, at low concentrations, and that animals at early stages of development are particularly sensitive to their effects. All species, including domestic and wild animals and humans, can be affected. Thus, there are potential adverse implications of exposure for farm and companion animal productivity and health, and associated economic implications. While anthropogenic pollutants exert subtle, but important, adverse effects on animal health and productivity, these should be weighed against the benefits associated with the use of these compounds, particularly in relation to food production and short-term determinants of animal health. However, it is suggested that it may be necessary to regulate future production and use of some of these compounds in order to ensure long term sustainability of production systems.
\end{abstract}

\section{Introduction}

Pollution is a natural phenomenon. For example, crude oil constantly leaks from below the Earth's crust in many areas, volcanic outputs include multiple toxic gases and forest fires result in the production of toxic hydrocarbons. However, both the amounts and range of types of pollutants released into the environment have been greatly increased by human action since metals were first smelted, thousands of years ago, increasing environmental levels of heavy metals [1]. The increases have been particularly marked during the last 60 years, as many new organic chemicals have been synthesised and used in thousands of products. The recently-synthesised compounds are chemically-diverse in nature, each having been created to have certain properties e.g. organochlorine compounds such as DDT are highly effective insecticides, phthalates are used as softening agents in

Correspondence: stewart.rhind@hutton.ac.uk

The James Hutton Institute, Craigiebuckler, Aberdeen, AB15 8QH, UK plastics, polybrominated diphenyl ethers (PBDEs) are effective fire retardants used in electrical equipment and furnishings, and polychlorinated biphenyls (PCBs) were used, formerly, as coolants in electrical equipment [2]. Some others are by-products of combustion of the fossil fuels essential for modern lifestyles (polycyclic aromatic hydrocarbons; PAHs) [3,4]. All are found in the environment, although generally at very low concentrations.

The significance of this change in the nature and amount of pollutants lies in the fact that many of these chemicals have been found to perturb animal physiology, even although in most cases they are entirely synthetic and there is no naturally-occurring equivalent. Many of these compounds can bind to cellular receptors or otherwise interfere with hormonal signalling and enzyme systems in species as diverse as bacteria [5] and mammals [6]. Consequently, they have the capacity to disrupt normal endocrine function and are collectively described as endocrine disrupting compounds (EDCs). In addition to these organic pollutants, elemental pollutants, such as 
lead and mercury [7] also contribute to the pollutant burden and associated adverse physiological effects, sometimes acting in concert with organic pollutants [8].

Additional classes of anthropogenic compounds implicated in disruptive effects include some used to directly enhance animal and human health (analgesic pharmaceuticals; [9]) and crop production (nitrate fertilisers; [10]). All of these pollutants have become ubiquitous in the environment.

\section{Laboratory investigation of mechanisms and effects}

Arguably, issues of environmental pollution and animal and human health first achieved prominence with the publication of Silent Spring [11]. This highlighted the effects of some of the new chemicals on wildlife and probably stimulated some of the many detailed studies of effects and mechanisms of action.

Many of the studies designed to elucidate mechanisms of action have involved laboratory rodents subjected to high level, short-term, exposures to single chemicals. Such studies have clearly shown that such exposure could induce structural and physiological changes in the reproductive system [12,13] and could compromise immune function $[14,15]$. Such studies also contribute to understanding of the underlying mechanisms of action of EDCs. In parallel with the laboratory studies, field observations of a wide range of species showed further evidence of adverse physiological effects, particularly in relation to reproduction $[16,17]$ with associated effects on populations [18]. However, many of these observations concerned abnormally high levels of exposure associated with accidental releases of pollutants or with other unusual patterns of exposure (e.g. employment in factories where EDCs were used in manufacturing processes). Perhaps unsurprisingly, concerns about anthropogenic environmental pollutants remained relatively muted for some time because both field observations and laboratory studies involved high levels of single chemicals, making, it is easy to dismiss the observed effects as irrelevant in most circumstances. Environmental (low) concentrations of these compounds were seldom associated with apparent adverse effects on either animals or humans. Furthermore, many of the compounds concerned were of great value to crop production and disease control (herbicides and pesticides) or contributed to more comfortable (electrical equipment) or safer lifestyles (fire retardants) and the will to investigate possible adverse effects may have been limited.

\section{"Real world" exposure patterns are different}

It is often suggested that low concentrations of environmental pollutants are of no concern because, in most circumstances, concentrations are below the No Observed Effect Levels (NOEL); i.e. environmental levels of each individual chemical have been shown to be below the minimum concentrations known to induce a physiological response. However, this argument fails to take account of several factors:

\section{a) Mixtures}

It is now well recognised that EDCs act additively $[19,20]$ and, possibly, synergistically [21] on physiological systems i.e. the combined effects of multiple EDCs, each of which is present at concentrations too low to induce a response, can induce adverse effects.

\section{b) Exposure differs with age and stage}

It is often assumed that exposure to EDCs is similar in adult and fetal / juvenile stages of development and that they are subject to equivalent pollutant insults. In fact, studies of sheep have shown that fetal tissue concentrations of most EDC classes are lower than those of their dams, although some can be preferentially accumulated in fetal tissues [22,23]. This is presumably as a result of a shorter period of exposure in the fetus and differences between the fetus and dam in uptake, metabolism and excretion. In some animal groups, the insult may differ with stage of development because food sources, and therefore pollutant exposure patterns, differ e.g. immature ruminants feed on milk while mature animals are herbivorous; similarly, developing poultry derive nutrient from egg yolk while adults have very different food sources. These differences make it difficult to extrapolate tissue burden data across animals at different stages of development or to determine a critical level of exposure.

\section{c) Sensitivity differs with age and stage}

The occurrence of lesser tissue EDC burdens in younger animals might be assumed to be associated with a lesser risk of disruption. However, like exposure rate, susceptibility to disruption by environmental pollutants differs with age being greater during early developmental stages [24]. Studies of sheep have shown that exposed fetuses exhibit disrupted development even although some equivalent effects are absent in their dams $[25,26]$. Thus, the NOEL is different for animals at different stages of development.

\section{d) Individuals and species differ}

Individual animals exhibit a very high degree of variation in the rate of tissue accumulation of EDCs even when apparently exposed in an identical way; this presumably reflects differences between individuals in uptake, metabolism and excretion [2]. However, it should be noted that the capacity to metabolise pollutants is highly dependent, also, on species [27] and so extrapolation of the NOEL between species requires caution. 


\section{Farmed animals}

Initial concerns about EDCs were centred, primarily, on terrestrial, vertebrate wildlife, because it was in wild animals that adverse effects were first noted, but subsequent research has implicated EDCs in effects on farm animals [2], marine, freshwater and terrestrial invertebrates [28-30] and humans $[31,32]$.

Modern husbandry practices and modern household environments are both associated with increased exposure to the ubiquitous EDCs through food, water, inhaled air and administered pharmaceuticals [33]. Interest in environmental pollutants with respect to animals reared for food or as pets lies in many different areas. Consumers of farm animal products are often concerned about possible health risks associated with contaminated meat and dairy products while producers are concerned with both the image associated with their products and its monetary value. Pet owners have concerns about their animal's health and welfare. Consequently, veterinarians have an interest in all of these issues and species.

One aspect of exposure of farm animals that may change in the future is related to the increasing scarcity and cost of oil and phosphate, both of which are essential for the production of inorganic fertilisers; the increasing cost of such fertiliser, together with concerns about pollution, is increasing the pressure to recycle food waste, green waste and sewage sludge to land. All of these recycled products provide valuable plant nutrient but some also contain anthropogenic pollutants. There are divergent views with regard to the importance, in relation to animal productivity and health, of prolonged, low level, exposure to these pollutants following application of waste to land. In an extensive review, Smith [34] suggested that the application of sewage sludge to land was of little concern with respect to soil, animal or human health because rates of transfer into plants and animals were likely to be insignificant. Indeed, studies of tissue levels of several classes of EDCs (phthalate, PCBs, PBDEs and PAHs) suggest that exposure of sheep to pastures fertilised with sewage sludge resulted in minimal increases in milk or tissue concentrations of these compounds, relative to control animals exposed to inorganic fertilisers [35-38]. However, numerous, subtle, adverse effects have been observed in the same sheep [39]. While exposed animals appeared entirely normal, superficially, they exhibited many adverse changes in underlying physiology which had the potential to compromise reproductive performance. Specifically, exposure to sludge-treated pastures and associated EDCs has been shown to be associated with i) perturbed activity of several fetal hypothalamic neurotransmitter systems [25,26], ii) reduced fetal testis Leydig and Sertoli cell numbers and testosterone production [40] and associated germ cell numbers in the adult [41] and iii) increased fetal ovarian oocyte expression of the pro-apoptotic protein BAX and altered expression of many other fetal ovarian proteins [42]. In addition, preliminary data indicate that there may be disruption of maternal mammary structure [43] and altered protein expression in the fetal uterus [44].

Perturbation of non-reproductive systems has also been reported with sludge exposure being associated with reduced numbers of fetal thyroid follicles and reduced maternal T3 and T4 concentrations [45] and changes in offspring behaviour [46] and adult bone structure [47,48]. While not measured in the sheep studies, in other species effects of EDC exposure on obesogenic systems [49,50] and cardiovascular function have been recorded [51,52] and it is possible that similar disruption could occur in sludge-exposed ruminants or other animals exposed to an enhanced EDC insult.

In view of these observations, it might be expected that there would be evidence of reduced reproductive success in farmed animals as a result of increased environmental exposure to EDCs. At this time, evidence is scarce. Meijer et al. [53] reported a small reduction in fertility and milk production in dairy cows exposed to sewage-contaminated water and attributed the effect to the pollutants present. The high-yielding dairy cow has been the subject of much research because she exhibits a long-term decline in fertility but the underlying causes of this decline are not well understood. Nutritional and genetic factors have been implicated [54] but while, undoubtedly, they are involved, environmental pollutants may be acting in conjunction with them to exacerbate the decline in fertility through additive, subtle effects on gene expression and/or disruption of endocrine signals. The observations of Meijer et al. [53] may simply be indicative of a more general, largely invisible, effect of chronic, low level, environmental exposure to EDCs.

With regard to male animals, a decline in semen quality might be expected in the light of increased environmental exposure to EDCs and the effects on testis structure and function described above. One study of several farm species showed no reduction in sperm counts over a period of six decades [55]. However, it should be noted that the animals studied were selected for high fertility and may not be representative of the normal population. Furthermore, domestic ruminants store sperm and so may appear to have a high sperm count even when sperm production is reduced. Another study of bull semen [56] appeared to indicate a temporal decline in semen quality during the 1970s with an associated, anomalous improvement in sperm morphology and motility. It was concluded that there were some methodological inconsistencies which partially compromised the interpretation of the results but it was also concluded that the decline could not be readily linked to EDC exposure since semen quality subsequently 
improved. It seems likely that the issue is complex; it may involve environment/genotype interactions and a comprehensive understanding of the effects of environmental levels of EDCs on male fertility, or lack of them, may be some time off.

To date, little work has been done concerning effects of EDCs on domestic poultry but there is little reason to doubt that their physiology may be affected, also, since studies of wild birds have shown adverse effects of various EDCs on aspecets as diverse as egg shell formation and embryo survival $[57,58]$ and brain function, as indicated by altered song patterns [15].

In holarctic regions, farming of animals for fur is common; these species (e.g. mink, arctic fox, etc) are carnivores, near to the top of the food chain, and accumulate relatively high concentrations of pollutants in their tissues; they too exhibit adverse effects on embryo and offspring survival when exposed to specific dietary EDCs [59].

Finally, a range of fish species are farmed throughout the world; some of them are exposed to higher rates of pollutant exposure than wild fish [60] because they are fed on products containing other fish and associated accumulated pollutants. While most concern is focussed on potential effects on human health, such elevated tissue burdens may have physiological / health consequences for the fish themselves. Consumers are concerned about tissue EDC accumulation but veterinarians may have concerns about potential reproductive or immuno-suppressive effects of EDC burdens. While there do not appear to be significant concerns about such effects, to date, it should be noted that effects of environmental pollutants on reproductive physiology [61] of wild fish species have been reported indicating potential susceptibility.

\section{Domestic pets}

While no owner would wish to expose their much-loved companion animals to EDCs, as carnivores, dogs and cats are exposed to EDCs in their food [62]. Also, frequently they live indoors where EDC concentrations tend to be elevated relative to outdoor air [63] and so, like humans, they are exposed to a wide range of household EDCs, in part, owing to their close proximity to the ground where they are exposed to soil and house dust into which some EDCs such as PBDEs may leach [64] and because they have a tendency to consume items other than conventional foodstuffs. To date, such animals have been studied little but, as with domestic animals and humans, economic interests may cause this to change if effects are demonstrated.

\section{Other commercially important species}

While not, typically, the subject of conventional veterinary treatments, the commercial importance of some invertebrate groups should not be forgotten. Honey bees are clearly of great economic importance and populations in Europe and North America appear to be under threat from a combination of factors, possibly including exposure to endocrine disrupting, agricultural chemicals [65]. Other invertebrate groups of commercial interest include marine and freshwater shellfish. Much of the interest in freshwater has concerned effects of EDCs in sewage on fish populations but lower profile, invertebrate species are also affected. For example, freshwater pearl mussels, already under threat from over-exploitation, are further compromised by exposure to the antidepressant drug fluoxetine (Prozac) present in sewage effluent discharged into rivers; exposure causes premature release of their larvae, with associated reductions in their survival [66]. Effects of tributyl tin, an anti-fouling agent used in marine paints, has long been recognised as a potent disruptor of dogwhelk reproduction [67] but larval stages of bivalve molluscs, some of which are significant commercial species, are highly sensitive to this EDC [68]. While large, mammalian species generally have a higher profile and are the subject of greater management and veterinary inputs, the commercial and biological significance of more lowly species should not be underestimated and neither should the potential adverse effects on them of environmental pollutants.

\section{Understanding EDC actions}

As indicated above, exposure of both species and individuals to pollutants is highly variable, depending on environment, diet and veterinary medical treatments, and multiple factors influence the animals' responses. The occurrence of disruptions of reproduction and health that can be clearly attributed to the effects of pollutants is rare, reflecting the fact that effects are generally subtle, involving changes in gene expression and the structure and function of internal organs but not gross changes in health or reproductive performance. However, such subtle effects can be greatly exacerbated in animals subject to additional stressors; thus prediction of responses to exposure is difficult. For example, depending on the species and environment, stressors can be nutritional [69], osmotic [70] or thermal [71]. In each of these examples, the effect of the combination of insults (pollutant burden and other stressor) resulted in differences in tissue EDC burdens or enhanced susceptibility to the pollutants. Interactions between EDCs and other factors are poorly understood but may be a significant factor in animal health because subtle, underlying physiological disruptions that have no detectable effect in the healthy, unstressed, animal may become important when combined with other influences. Domestic animals can also suffer from such stressors and, in modern production systems, particularly social stressors 
[72] but the effects of such factors on responses to EDCs has been little investigated in domestic animals at this time.

\section{The future}

Since EDCs are not causing widespread, acute, animal health issues, they may seem unimportant. However, it is important to remember that many of their effects are very subtle, and include changes in expression of particular genes, in fetal organ development and in animal reproductive performance and health, none of which are readily detected. Evidence of health effects in humans include increased incidences of testicular abnormalities and reduced fertility [22]. However, while the body of circumstantial evidence indicating a probable role of EDCs in these effects is large and rapidly growing, generally, it is virtually impossible to demonstrate, directly, causal links between EDC exposure and effect.

Setting aside the overarching threat that EDCs may pose to animal and human health and ecosystem sustainability, in practice, effects of EDCs may be of concern because of small effects on the long term health and productivity of domestic animals [39], particularly if they are acting in conjunction with other adverse influences. Thus, subtle changes in fetal development may result in a chronic and equally subtle, adverse effects in adult growth, reproduction or health which may be economically significant but are not readily corrected by management or veterinary intervention.

The extent to which animals are exposed to EDCs, and therefore the associated risk, is likely to depend on species and management practice e.g. with increasing costs of artificial fertiliser, the application to land of processed wastes such as sewage sludge and green waste compost is increasing. Production systems are also moving to the extremes; while low input systems are increasingly favoured in hill and upland areas, this in turn results in more intensive production and increased pesticide use in areas of high quality land and perhaps higher densities of animals with associated social stresses. Each trend has implications for the rate of EDC exposure and for the effects of exposure, as indicated above.

It is easy to focus entirely on the negative consequences associated with the production and use of EDCs but it is important to recognise the need for a more balanced view. Taking the use of analgesics as an example, while they may have disruptive effects in fetal development, this disbenefit must be considered in the light of the enormous potential benefits of their use. Similarly, while pesticides, herbicides, components of plastics and many other everyday products contain EDCs which may pose an insidious threat to animal health and productivity, they also provide massive benefits in terms of food production and human and animal health. Thus, optimising their production and use may not be easy and will certainly require a better understanding of the rates of exposure to, and actions of, these chemicals.

Published: 24 February 2012

\section{References}

1. Hong S, Candelone JP, Patterson CC, Boutron CF: History of ancient copper smelting pollution during Roman and medieval times recorded in Greenland ice. Science 1996, 272:246-249.

2. Rhind SM: Are endocrine disrupting compounds a threat to farm animal health, welfare and productivity? Reprod Domest Anim 2005, 40:282-290.

3. Boström CE, Gerde P, Hanberg A, Jernström B, Johansson C, Kyrklund T, Rannug A, Törnqvist M, Victorin K, Westerholm R: Cancer risk assessment, indicators, and guidelines for polycyclic aromatic hydrocarbons in the ambient air. Environ Health Perspect 2002, 110(Suppl 3):451-488.

4. Yunker MB, Macdonald RW, Vingarzan R, Mitchell RH, Goyette D, Sylvestre S: $\mathrm{PAHs}$ in the Fraser River basin: a critical appraisal of $\mathrm{PAH}$ ratios as indicators of PAH source and composition. Org Geochem 2002, 33:489-515.

5. Fox JE: Chemical communication threatened by endocrine-disrupting compounds. Environ Health Perspect 2004, 112:648-653.

6. Toppari J, Larsen JC, Christiansen P, Giwercman A, Grandjean P, Guillette LJ, Jegou $B$, Jensen TK, Jouannet $P$, Keiding $N$, Leffers $H$, McLachlan JA, Meyer O, Muller J, Meyts ER, Scheike T, Sharpe R, Sumpter J, Skakkebaek NE: Male reproductive health and environmental xenoestrogens. Environ Health Perspect 1996, 104(Suppl 4):741-803.

7. Liu Y, McDermott S, Lawson A, Aelion CM: The relationship between mental retardation and developmental delays in children and the levels of arsenic, mercury and lead in soil samples taken near their mother's residence during pregnancy. Int J Hyg Envir Heal 2010, 213:116-123.

8. Bemis JC, Seegal RF: Polychlorinated biphenyls and methylmercury act synergistically to reduce rat brain dopamine content in vitro. Environ Health Perspect 1999, 107:879-885.

9. Kristensen DM, Hass U, Lesné L, Lottrup G, Jacobsen PR, DesdoitsLethimonier C, Boberg J, Petersen JH, Toppari J, Jensen TK, Brunak S, Skakkebaek NE, Nellemann C, Main KM, Jégou B, Leffers $H$ : Intrauterine exposure to mild analgesics is a risk factor for development of male reproductive disorders in human and rat. Hum Reprod 2011, 26:235-244.

10. Guillette $L J \mathrm{Jr}$, Edwards TM: Environmental influences on fertility: can we learn lessons from wildlife? Fertil Steril 2007, 89(2 Suppl):e21-e24.

11. Carson R: Silent Spring. Boston, USA: Houghton Mifflin Co.

12. Susiarjo M, Hassold TJ, Freeman E, Hunt PA: Bisphenol A exposure in utero disrupts early oogenesis in the mouse. PLoS Genet 2007, 3:e5.

13. Steinberg RM, Walker DM, Juenger TE, Woller MJ, Gore AC: Effects of perinatal polychlorinated biphenyls on adult female rat reproduction: development, reproductive physiology, and second generation effects. Biol Reprod 2008, 78:1091-1101.

14. Vine MF, Stein L, Weigle K, Schroeder J, Degnan D, Chiu-kit JT, Hanchette C, Backer $L$ : Effects on the immune system associated with living near a pesticide dump site. Environ Health Perspect 2000, 108:1113-1124.

15. Markman S, Leitner S, Catchpole C, Barnsley S, Müller CT, Pascoe D, Buchanan KL: Pollutants increase song complexity and the volume of the brain area HVC in a songbird. PLOS One 2008, 3(2):e1674.

16. Colborn T, Vom Saal AM, Soto AM: Developmental effects of endocrine disrupting chemicals in wildlife and human. Environ Health Perspect 1993, 101:378-384

17. Guillette LJ, Gross TS, Masson JR, Matter JM, Percival HF, Woodward AR: Developmental abnormalities of the gonad and abnormal sex hormone concentrations in juvenile alligators from contaminated and control lakes in Florida. Environ Health Perspect 1994, 102:680-688.

18. IEH: IEH Assessment of the Ecological Significance of Endocrine Disruption: Effects on Reproductive Function and Consequences for Natural Populations (Assessment A4). Leicester, UK: MRC Institute for Environment and Health; 1999.

19. Crofton KM, Craft ES, Hedge JM, Gennings C, Simmons JE, Carchman RA Carter WH, deVito MJ: Thyroid-hormone-disrupting chemicals: evidence for dose-dependent additivity or synergism. Environ Health Perspect 2005, 113:1549-1554 
20. Kortenkamp A: Ten years of mixing cocktails: a review of combination effects of endocrine-disrupting chemicals. Environ Health Perspect 2007, 115(Suppl 1):98-105.

21. Hauser R, Williams P, Altshul L, Calafat AM: Evidence of interaction between polychlorinated biphenyls and phthalates in relation to human sperm count. Environ Health Perspect 2005, 113:425-430.

22. Rhind SM: Anthropogenic pollutants - a threat to ecosystem sustainability and our survival? Philos Trans R Soc Lond B Biol Sci 2009, 364:3391-3401.

23. Rhind SM, Kyle CE, Mackie C, McDonald L, Zhang Z, Duff El, Bellingham M, Amezaga MR, Mandon-Pepin B, Loup B, Cotinot C, Evans NP, Sharpe RM, Fowler PA: Maternal and fetal tissue accumulation of selected endocrine disrupting compounds (EDC) following exposure to sewage sludgetreated pastures before or after conception. J Environ Monitor 2010, 12:1582-1593

24. IPCS: In Global Assessment of the State-of-the-Science of Endocrine Disruptors Damstra T, Barlow S, Bergman A, Kavlock R, Van Der Kraak G 2002 [http:// ehp.niehs.nih.gov/who/preface.pdf].

25. Bellingham M, Fowler PA, Amezaga MR, Rhind SM, Cotinot C, MandonPepin B, Sharpe RM, Evans NP: Exposure to environmental endocrine disrupting compounds in sewage sludge: effects on the KiSS-1/GPR54 system in ovine hypothalamus and pituitary gland. Environ Health Perspect 2009, 117:1556-1562.

26. Bellingham M, Fowler PA, Amezaga MR, Whitelaw CM, Rhind SM, Cotinot C, Mandon-Pepin B, Sharpe RM, Evans NP: Fetal hypothalamic and pituitary expression of $\mathrm{GnRH}$ and galanin systems is disturbed by exposure to sewage sludge chemicals via maternal ingestion. J Neuroendocrinol 2010, 22:527-533.

27. Watkins JB, Klaassen CD: Xenobiotic biotransformation in livestock: comparison to other species commonly used in toxicity testing. J Anim Sci 1986, 63:933-942

28. Gibbs P, Bryan G: TBT paints and the demise of the dog-whelk, Nucella lapillus (Gastropoda). Oceans 1987, 19:1482-1487.

29. Bruce L, McCracken D, Foster G, Aitken M: The effects of sewage sludge on grassland euedaphic and hemiedaphic collembolan populations. Pedobiologia 1999, 43:209-220.

30. Beketov MA, Liess M: Acute contamination with esfenvalerate and food limitation: chronic effects on the mayfly, Cloeon dipterum. Environ Toxicol Chem 2005, 24:1281-1286.

31. Fei C, McLaughlin JK, Lipworth L, Olsen J: Maternal levels of perfluorinated chemicals and subfertility. Hum Reprod 2009, 1:1-6.

32. Gray J, Evans N, Taylor B, Rizzo J, Walker M: The connection between breast cancer and the environment. Int J Occup Environ Health 2009, 15:43-78.

33. Boerjan ML, Freijnagel S, Rhind SM, Meijer GAL: The potential reproductive effects of exposure of domestic ruminants to endocrine disrupting compounds. Anim Sci 2002, 74:3-12.

34. Smith SR: Organic contaminants in sewage sludge (biosolids) and their significance for agricultural recycling. Philos Transact A Math Phys Eng SC 2009, 367:4005-4041.

35. Rhind SM, Kyle CE, Owen J: Accumulation of potentially toxic metals in the liver tissue of sheep grazed on sewage sludge-treated pastures. Anim Sci 2005, 81:107-113.

36. Rhind SM, Kyle CE, Telfer G, Duff El, Smith A: Alkyl phenols and diethylhexyl phthalate in tissues of sheep grazing pastures fertilised with sewage sludge or inorganic fertilizer. Environ Health Perspect 2005, 113:447-453.

37. Rhind SM, Kyle CE, Mackie C, Telfer G: Effects of exposure of ewes to sewage sludge-treated pasture on phthalate and alkyl phenol concentrations in their milk. Sci Total Environ 2007, 383:70-80.

38. Rhind SM, Kyle CE, Mackie C, McDonald L: Accumulation of endocrine disrupting compounds (EDCs) in sheep fetal and maternal liver tissue following exposure to pastures treated with sewage sludge. J Environ Monitor 2009, 11:1469-1476.

39. Rhind SM, Evans NP, Bellingham M, Sharpe RM, Cotinot C, Mandon-Pepin B, Fischer B, van der Zalm E, Hart K, Schmidt JS, Amezaga MR, Sinclair KD, Lea RG, Pocar P, Fischer B, Fowler PA: Effects of pollutants on the reproduction and welfare of ruminants. Animal 2010, 4:1227-1239.

40. Paul C, Rhind SM, Kyle CE, Scott H, McKinnell C, Sharpe RM: Cellular and hormonal disruption of fetal testis development in sheep reared on pasture treated with sewage sludge. Environ Health Perspect 2005, 113:1580-1587.

41. Bellingham M, McKinnell C, Fowler PA, Amezaga MR, Rhind SM, Cotinot C, Mandon-Pepin B, Evans NP, Sharpe RM: Fetal and post-natal exposure to sewage sludge chemicals via maternal ingestion disrupts adult male testicular function. Int J Androl 2012.

42. Fowler PA, Dora N, McFerran H, Amezaga MR, Miller DW, Lea RG, Cash P, McNeilly AS, Evans NP, Cotinot C, Sharpe RM, Rhind SM: In-utero exposure to low doses of environmental pollutants disrupts fetal ovarian development in sheep. Mol Hum Reprod 2008, 14:269-280.

43. Fowler PA, Gordon KL, Thow CA, Cash P, Miller DW, Lea RG, Rhind SM: Exposure to sewage sludge disrupts ewe mammogenesis. Proceedings of the Society for the Study of Reproduction and Fertility York; 2007.

44. Amezaga MR, Wilson J, Bellingham M, Evans NP, Mandon-Pepin B, Cotinot C, Sharpe RM, Rhind SM, Hombach-Klonisch S, Klonisch T, Fowler PA: Exposure to a cocktail of environmental chemicals alters the fetal uterus. Proceedings of the Society for the Study of Reproduction and Fertility Edinburgh; 2009.

45. Hombach-Klonisch S, Danescu A, Begum F, Fowler PA, Amezaga MR, Rhind SM, Klonisch T: Periconception changes in maternal exposure to sewage sludge disrupts fetal thyroid gland development. Proceedings of the 6th Copenhagen Workshop on Endocrine Disruptors Copenhagen; 2011.

46. Erhard H, Rhind SM: Prenatal and postnatal exposure to environmental pollutants in sewage sludge alters emotional reactivity and exploratory behaviour in sheep. Sci Total Environ 2004, 332:101-108.

47. Lind PM, Gustavsson M, Hermsen S, Larsson S, Kyle CE, Örberg J, Rhind SM: Exposure to sewage sludge disrupts bone tissue homeostasis in sheep. Sci Total Environ 2009, 407:2200-2208.

48. Lind PM, Öberg D, Larsson S, Kyle CE, Örberg J, Rhind SM: Ewes exposed to multiple endocrine disrupting pollutants through sewage sludgefertilised pasture show an anti-estrogenic effect in their trabecular bone. Sci Total Environ 2010, 408:2340-2346.

49. Grun F, Blumberg B: Environmental obesogens: organotins and endocrine disruption via nuclear receptor signalling. Endocrinology 2006, 147: S50-S55.

50. Grun F, Watanabe H, Zamanian Z, Maeda L, Arima K, Cubacha R, Gardiner DM, Kanno J, Iguchi T, Blumberg B: Endocrine disrupting organotin compounds are potent inducers of adipogenesis in vertebrates. Mol Endocrinol 2006, 20:2141-2155.

51. Lind PM, Öberg J, Edlund UB, Sjoblom L, Lind L: The dioxin-like pollutant PCB 126 (3,3',4,4',5-pentachlorobiphenyl) affects risk factors for cardiovascular disease in female rats. Toxicol Lett 2004, 150:293-299.

52. Ha MH, Lee DH, Jacobs DR: Association between serum concentrations of persistent organic pollutants and self-reported cardiovascular disease prevalence: results from the National Health and Nutrition Examination Survey, 1999-2002. Environ Health Perspect 2007, 115:1204-1209.

53. Meijer GAL, de Bree JA, Wagenaar JA, Spoelstra SF: Sewerage overflows put production and fertility of dairy cows at risk. J Environ Qual 1999, 28:1381-1383.

54. Friggens NC, Disenhaus C, Petit HV: Nutritional sub-fertility in the dairy cow: towards improved reproductive management through a better biological understanding. Animal 2010, 4:1197-1213.

55. Setchell B: Sperm counts in semen of farm animals 1932-1995. Int J Androl 1997, 20:209-214.

56. Wahl RL, Reil JS: Temporal trends in bull semen quality: a comparative model for human health. Environ Res 2009, 109:273-280.

57. Faber R, Hickey J: Eggshell thinning, chlorinated hydrocarbons, and mercury in inland aquatic bird eggs, 1969 and 1970. Pestic Monit J 1973, 7:27-36.

58. Bosveld ATC, van den Berg M: Reproductive failure and endocrine disruption by organohalogens in fish-eating birds. Toxicology 2002, 181182:155-159.

59. Brunstrom B, Lund BO, Bergman A, Asplund L, Athassiadis I, Athanasiadou M, Jensen S, Orberg J: Reproductive toxicity in mink (Mustela vison) chronically exposed to environmentally relevant polychlorinated biphenyl concentrations. Environ Toxicol Chem 2001, 20:2318-2327.

60. Hites RA, Foran JA, Carpenter DO, Hamilton MC, Knuth BA, Schwager SJ: Global assessment of organic contaminants in farmed salmon. Science 2004, 303:226-229. 
61. Sumpter JP, Jobling S: Vitellogenesis as a biomarker for estrogenic contamination of the aquatic environment. Environ Health Perspect 1995, 103(Suppl 7):173-178.

62. Venier M, Hites RA: Flame retardants in the serum of pet dogs and in their food. Environ Sci Technol 2011, 45:4602-4608.

63. Rudel RA, Perovich $\mathrm{L}$ : Endocrine disrupting chemicals in indoor and outdoor air. Atmos Environ 2009, 43:170-181.

64. Deng WJ, Zheng JS, Bi XH, Fu JM, Wong MH: Distribution of PBDEs in air particles from an electronic waste recycling site compared with Guangzhou and Hong Kong, South China. Environ Int 2007, 33:1063-1069.

65. Mullin CA, Frazier M, Frazier JL, Ashcraft S, Simonds R, van Engelsdorp D, Pettis JS: High levels of miticides and agrochemicals in North American apiaries: implications for honey bee health. PLoS One 2010, 5(3):e9754.

66. Bringolf RB, Heltsley RM, Newton TJ, Eads CB, Fraley SJ, Shea D, Cope WG: Environmental occurrence and reproductive effects of the pharmaceutical Fluoxtine in native freshwater mussels. Environ Toxicol Chem 2010, 29:1311-1318.

67. Blaber SJM: The occurrence of a penis-like outgrowth behind the right tentacle in spent females of Nucella lapillus (L.). Proc Malacol Soc Lond 1970, 39:231-233.

68. His E, Beiras R, Seaman MNL: The assessment of marine pollution: bioassays with marine embryos and larvae. Adv Mar Biol 1999, 37:1-178

69. Wienburg CL, Shore RF: Factors influencing liver PCB concntrations in sparrowhawks (Accipiter nisus), kestrels (Falco tinnunculus) and herons (Ardea cinerea) in Britain. Environ Pollut 2004, 132:41-50.

70. McCormick SD, O'Dea MF, Moeckel AM, Lerner DT, Bjornsson BT: Endocrine disruption of parr-smolt transformation and seawater tolerance of Atlantic salmon by 4-nonylphenol and 17beta-estradiol. Gen Comp Endocrinol 2005, 142:280-288

71. Camus L, Davies PE, Spicer Jl, Jones MB: Temperature dependent physiological response of Carcinus maenas exposed to copper. Mar Environ Res 2004, 58:781-785.

72. Hanlon AJ, Rhind SM, Reid HW, Burrells C, Lawrence AB: Effects of repeated changes in group composition on immune response, behaviour, adrenal activity and liveweight gain in farmed red deer yearlings. Appl Anim Behav Sci 44:57-64.

doi:10.1186/1751-0147-54-S1-S2

Cite this article as: Rhind: Anthropogenic pollutants - an insidious threat to animal health and productivity? Acta Veterinaria Scandinavica 2012 54(Suppl 1):S2.

\section{Submit your next manuscript to BioMed Central and take full advantage of:}

- Convenient online submission

- Thorough peer review

- No space constraints or color figure charges

- Immediate publication on acceptance

- Inclusion in PubMed, CAS, Scopus and Google Scholar

- Research which is freely available for redistribution 